\title{
Ultraviolet Irradiation Effect on Apple Juice Bioactive Compounds during Shelf Storage
}

\author{
Edmundo Juarez-Enriquez ${ }^{1}$, Ivan Salmerón ${ }^{2,+}{ }^{\dagger}$, Nestor Gutierrez-Mendez ${ }^{2,+}$ \\ and Enrique Ortega-Rivas ${ }^{2, *}$ \\ 1 Centro de Investigación en Alimentación y Desarrollo, Av. Rio Conchos S/N, Parque Industrial, Cd. \\ Cuauhtémoc, Chihuahua 31570, Mexico; edjuen@gmail.com \\ 2 Graduate Program in Food Science and Technology, The Graduate School, Autonomous University of \\ Chihuahua, Chihuahua 31125, Mexico; isalmeron@uach.mx (I.S.); ngutierrez@uach.mx (N.G.-M.) \\ * Correspondence: eortegar@uach.mx; Tel./Fax: +52-614-424-1868 \\ + These authors contributed equally to this work.
}

Academic Editors: Monique Lacroix and J. Scott Smith

Received: 12 September 2015; Accepted: 28 December 2015; Published: 18 February 2016

\begin{abstract}
Clarified and standardized apple juice was ultraviolet-irradiated to inactivate polyphenol oxidase enzyme and microbiota, and its effect on bioactive compounds and stability during storage was also evaluated. Apple juice was irradiated with $345.6 \mathrm{~J} / \mathrm{cm}^{2}$ and treatment effect was evaluated in terms of color, antioxidant capacity, polyphenol content, $\mathrm{pH}$, titratable acidity and total soluble solids. Using a linear regression design, inactivation kinetic of polyphenol oxidase enzyme was also described. In addition, a repeated measures design was carried out to evaluate apple juice during 24 days of storage at $4{ }^{\circ} \mathrm{C}$ and $20^{\circ} \mathrm{C}$. After irradiation, reduction of antioxidant capacity was observed while during storage, ascorbic acid content decreased up to $40 \%$ and total polyphenol content remain stable. Ultraviolet irradiation achieved a complete inactivation of polyphenol oxidase enzyme and microbiota, keeping apple juice antioxidants during ultraviolet treatment and storage available until juice consumption. UV-treated apple juice can be used as a regular beverage, ensuring antioxidant intake.
\end{abstract}

Keywords: ultraviolet irradiation; non-thermal food preservation; bioactive compounds stability; apple juice storage

\section{Introduction}

A frequent consumption of apples has been correlated with healthy life, due to their antioxidant capacity and beneficial phytochemical compounds. Whole apple consumption promotes a LDL-cholesterol reduction [1], and polyphenols from apple juice help to reduce body fat [2]. Especially apple polyphenols have been linked with anticarcinogenic effects [3] and, most recently, referred to the prevention of colorectal cancer in man [4].

The presence and bioavailability of those beneficial compounds in processed apple juice are mainly related to the extraction and further preservation process [5]. Ultraviolet (UV) treatment has been used as an alternative preservation method for thermal treatment [6] to preserve those biochemical compounds.

Donahue et al. [7] and Basaran et al. [8] showed the UV treatment effectivity for pasteurization of cloudy and clear apple juice using E. coli as a target, reducing a minimum of five log cycles with 20 and $14 \mathrm{~mJ} / \mathrm{cm}^{2}$ irradiation, respectively. Later Caminity et al. [9] observed a negligible effect of UV dose on phenol content; however, a decrease in antioxidant capacity after treatment was noted. The 
aim of the present study was to investigate the effect of UV treatment on clarified apple juice and its evolution during 24 days of storage.

\section{Experimental Section}

\subsection{Raw Materials}

Golden delicious apples were donated by a local farmer and juice was extracted in a pilot scale vertical press. Ascorbic and citric acid $(800 \mathrm{mg} / \mathrm{L}$ and $325 \mathrm{mg} / \mathrm{L})$ were added to the juice prior to clarification process to prevent enzymatic oxidation and color changes [10]. Clarification was achieved with an enzymatic mixture of glucoamylase, pectin metil esterase, pectinlyase and polygalacturonase enzymes donated by ENMEX S.A de C.V. (DF, Tlalnepantla, Mexico) for $12 \mathrm{~h}$ at $4{ }^{\circ} \mathrm{C}$.

The reagents sodium carbonate, L-ascorbic acid, 2,6-dichloroindophenol, 2,2-diphenyl1-picrylhydrazyl and gallic acid where provided by Sigma (St Louis MO, USA). Metaphosphoric acid and methanol where obtained from Fisher (Pittsburgh PA, USA) and Folin-Ciocalteu solution was from MP Biomedicals (Solon OH, USA).

\subsection{Juice Characterization Colorimetric Measurements}

Titratable acidity, $\mathrm{pH}$ and soluble solids ( ${ }^{\circ}$ Brix) were determined by AOAC 942.1.15, AOAC 942.1.04 and AOAC 932.12 methods respectively. Soluble solids were evaluated as ${ }^{\circ}$ Brix at $20^{\circ} \mathrm{C}$ using an ABBE-3L Refractometer (Milton Roy Inc., Rochester, NY, USA). The $\mathrm{pH}$ was measured by direct reading at $20^{\circ} \mathrm{C}$ in an Orion Benchtop pH/ISE meter Model 420A (Orion Research Inc., Boston, MA, USA). Acidity was measured by titrating with $0.1 \mathrm{~N} \mathrm{NaOH}$ to a $\mathrm{pH}$ end-point of 8.2, the result being expressed as mg malic acid/mL of sample.

Ascorbic acid, Trolox Equivalent Antioxidant Capacity (TEAC) and total polyphenols content were determined according to the methodology reported by Juarez-Enriquez et al. [11]. The absorbance of the solutions was measured on a Pekin Elmer Lamda 25 (Waltham, Massachusetts, USA) and was correlated with its respective standard curve.

\subsection{Colorimetric Measurements}

Color components $\mathrm{L}$, a, and b, based on the Hunter system, were measured in $15 \mathrm{~mL}$ of juice using a hand-hold Tristimulus Colorimeter Konica Minolta CR-410 (NJ, USA) in a dark room with white background [12]. The mentioned components were transformed to hue $\left(H^{*}\right)$ and chroma $\left(C^{*}\right)$ indices $[13,14]$ by:

$$
\begin{aligned}
& H^{*}=\arctan \frac{b}{a} \\
& C^{*}=\sqrt{a^{2}+b^{2}}
\end{aligned}
$$

\subsection{Polyphenol oxidase (PPO) Activity Determination}

PPO activity was assayed using the method proposed by Cano et al. [15] with a modification. Aliquots of $0.2 \mathrm{~mL}$ of the clarified juice and $2.8 \mathrm{~mL}$ of a solution of $0.15 \mathrm{~mol} / \mathrm{L}$ catechol in $0.05 \mathrm{~mol} / \mathrm{L}$ sodium phosphate buffer $(\mathrm{pH}$ 6.5) were hand-mixed in a $3 \mathrm{~mL}$ plastic cell. The kinetic reaction was measured at $420 \mathrm{~nm}$ and $25{ }^{\circ} \mathrm{C}$ with the spectrophotometer. An increase of one absorbance unit in 10 min was defined as one enzyme unit.

\subsection{UV Treatment and Kinetic Data}

UV treatments were performed with an irradiation $0.032 \mathrm{~W} / \mathrm{cm}^{2}$ at $25{ }^{\circ} \mathrm{C}$ in a Trojan UV MAX C4 (Ontario, Canada) with capacity of $3000 \mathrm{~mL}$ and enabled to work in batch mode. In order to obtain the inactivation kinetic data, aliquots of $5 \mathrm{~mL}$ were extracted every $10 \mathrm{~min}$ for $2 \mathrm{~h}$ and kept refrigerated at $4{ }^{\circ} \mathrm{C}$ until PPO activity determinations. 


\subsection{Statistical Analysis}

All experiments were done in triplicate and significance level was set at 0.05. Data analysis was carried out with Minitab 16 (Minitab Inc., State College, PA, USA) using a General Linear Model (GLM) with Tukey test for data and means analysis. A linear regression design was performed in Minitab 16 to describe the inactivation kinetic of PPO enzyme. An additional repeated measures design was carried out with IBM SPSS v20 Software (IBM, New York, NY, USA) to analyze the effect of the storage time (24 days) in clarified apple juice processed with the calculated UV radiation for $100 \%$ PPO denaturation, over quality variables on juice stored at $4{ }^{\circ} \mathrm{C}$ and $20^{\circ} \mathrm{C}$.

\section{Results}

Table 1 shows all differences in physicochemical properties of thermal- and UV-clarified juice treatments and untreated juice. Brix degrees, acidity, color saturation, total polyphenol content and total ascorbic acid content do not present significant $(p>0.05)$ changes in UV-treated juice when compared with non-treated clarified juice. In this sense, $\mathrm{pH}$, acidity, Brix degrees, total polyphenol content and color saturation were stable with no significant $(p>0.05)$ changes in thermal-treated juice. On the other hand, significant $(p<0.05)$ changes after UV treatment on TEAC and color expressed as hue were observed.

Table 1. Changes in physicochemical properties after UV treatment.

\begin{tabular}{ccc}
\hline Property & Clarified Juice & UV Treatment \\
\hline $\mathrm{pH}$ & $3.74 \pm 0.01^{\mathrm{a}}$ & $3.54 \pm 0.03^{\mathrm{b}}$ \\
Malic acid eq. $(\mathrm{mg} / \mathrm{mL})$ & $6.19 \pm 0.04^{\mathrm{a}}$ & $6.06 \pm 0.04^{\mathrm{a}}$ \\
'Brix & $17.97 \pm 0.06^{\mathrm{a}}$ & $18.05 \pm 0.07^{\mathrm{a}}$ \\
Ascorbic acid (ppm) & $119.22 \pm 5.04^{\mathrm{a}}$ & $121.16 \pm 0.75^{\mathrm{a}}$ \\
TEAC (mM) & $10.99 \pm 0.16^{\mathrm{a}}$ & $9.85 \pm 0.96^{\mathrm{c}}$ \\
Gallic acid eq. $(\mathrm{mg} / \mathrm{L})$ & $343.17 \pm 1.02^{\mathrm{a}}$ & $346.02 \pm 5.04^{\mathrm{a}}$ \\
Hue & $81.37 \pm 0.59^{\mathrm{a}}$ & $87.57 \pm 0.51^{\mathrm{b}}$ \\
Chroma & $3.29 \pm 1.21^{\mathrm{a}}$ & $5.10 \pm 1.32^{\mathrm{a}}$ \\
\hline
\end{tabular}

* Any two means in the same row followed by same letter are not significantly different $(p>0.05)$ by analysis of variance.

Complete PPO enzyme inactivation was achieved after $180 \mathrm{~min}$, following a linear kinetic inactivation as described in Figure 1. The regression model was highly correlated (coefficient of determination $R^{2}=0.84$ ), and can be represented by the following relationship:

$$
Y=-0.003 X_{1}+0.5257
$$

where $Y$ is the PPO activity and $X_{1}$ is the treatment time with an irradiation of $0.032 \mathrm{~J} / \mathrm{cm}^{2}$. The total UV dose received by apple juice was $345.6 \mathrm{~J} / \mathrm{cm}^{2}$.

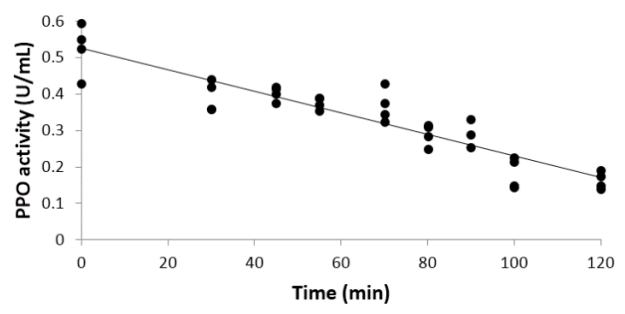

Figure 1. PPO deactivation kinetic by UV irradiation.

The physicochemical changes during the storage time of the UV-treated apple juice are shown in Table 2. Acidity, chroma, ascorbic acid content, total polyphenol content and TEAC parameters presented significant variation during the 24 days of storage at $4{ }^{\circ} \mathrm{C}$ and $20^{\circ} \mathrm{C}$. On the contrary, color change expressed as hue not was significantly $(p>0.05)$ affected during all storage time. 
Table 2. Evolution of physiochemical parameters on UV-treated apple juice for 24 days storage at $4{ }^{\circ} \mathrm{C}$ and $20^{\circ} \mathrm{C}$.

\begin{tabular}{|c|c|c|c|c|c|c|c|c|c|}
\hline Days & Temp $\left({ }^{\circ} \mathrm{C}\right)$ & $\mathrm{pH}$ & $\begin{array}{l}\text { Acidity } \\
\text { (mg/mL) }\end{array}$ & ${ }^{\circ}$ Brix & Hue & Chroma & $\begin{array}{l}\text { Ascorbic Acid } \\
(\mathrm{ppm})\end{array}$ & $\begin{array}{l}\text { Gallic Acid Eq. } \\
\text { (mg/L) }\end{array}$ & TEAC (mM) \\
\hline 1 & $4^{\circ} \mathrm{C}$ & $3.54 \pm 0.03^{\mathrm{a}}$ & $6.056 \pm 0.039^{a}$ & $18.15 \pm 0.07^{\mathrm{ab}}$ & $87.57 \pm 0.52^{a}$ & $5.10 \pm 1.32^{a}$ & $121.16 \pm 0.75^{a}$ & $347.70 \pm 4.58^{a}$ & $9.884 \pm 0.079^{a}$ \\
\hline 6 & $4^{\circ} \mathrm{C}$ & $3.50 \pm 0.03^{a, b}$ & $6.213 \pm 0.077^{a}$ & $18.25 \pm 0.07^{\mathrm{a}}$ & $87.59 \pm 0.41^{\mathrm{a}}$ & $4.18 \pm 0.64^{\mathrm{a}, \mathrm{b}}$ & $108.72 \pm 0.83^{b}$ & $334.35 \pm 1.11^{b}$ & $8.031 \pm 0.144^{b}$ \\
\hline 12 & $4^{\circ} \mathrm{C}$ & $3.48 \pm 0.02^{b}$ & $6.168 \pm 0.005^{\mathrm{a}}$ & $17.25 \pm 0.07^{c}$ & $88.01 \pm 0.52^{a}$ & $3.32 \pm 0.37^{\mathrm{a}, \mathrm{b}}$ & $105.60 \pm 0.62^{b, c}$ & $332.35 \pm 1.59^{b}$ & $7.445 \pm 0.571^{c}$ \\
\hline 18 & $4^{\circ} \mathrm{C}$ & $3.46 \pm 0.02^{b}$ & $6.663 \pm 0.131^{b}$ & $17.85 \pm 0.21^{a, b}$ & $87.55 \pm 0.95^{\mathrm{a}}$ & $3.98 \pm 0.14^{\mathrm{a}, \mathrm{b}}$ & $102.25 \pm 5.48^{c}$ & $318.06 \pm 1.97^{b}$ & $7.154 \pm 0.250^{c}$ \\
\hline 24 & $4^{\circ} \mathrm{C}$ & $3.44 \pm 0.02^{b}$ & $7.084 \pm 0.140^{c}$ & $17.70 \pm 0.14 b c$ & $85.74 \pm 1.41^{\mathrm{a}}$ & $3.11 \pm 0.13^{b}$ & $74.42 \pm 2.32^{d}$ & $337.86 \pm 5.06^{c}$ & $6.780 \pm 0.121^{c}$ \\
\hline 1 & $20^{\circ} \mathrm{C}$ & $3.54 \pm 0.03^{a}$ & $6.056 \pm 0.039^{a}$ & $18.05 \pm 0.07^{a}$ & $87.57 \pm 0.52^{a}$ & $5.10 \pm 1.32^{\mathrm{a}}$ & $121.16 \pm 0.75^{\mathrm{a}}$ & $347.70 \pm 4.58^{\mathrm{a}}$ & $9.884 \pm 0.079^{a}$ \\
\hline 6 & $20^{\circ} \mathrm{C}$ & $3.50 \pm 0.03^{\mathrm{a}}$ & $6.213 \pm 0.077^{a}$ & $17.95 \pm 0.07^{\mathrm{a}}$ & $86.72 \pm 0.45^{\mathrm{a}}$ & $3.68 \pm 0.52^{a, b}$ & $109.27 \pm 0.64^{b}$ & $330.21 \pm 1.11^{b}$ & $8.031 \pm 0.144^{b}$ \\
\hline 12 & $20^{\circ} \mathrm{C}$ & $3.51 \pm 0.03^{\mathrm{a}}$ & $7.017 \pm 0.205^{b}$ & $17.70 \pm 0.14^{\mathrm{a}}$ & $88.02 \pm 0.85^{a}$ & $2.91 \pm 0.37^{b}$ & $106.14 \pm 0.93^{c}$ & $310.09 \pm 11.92^{c}$ & $7.751 \pm 0.187^{b}$ \\
\hline 18 & $20{ }^{\circ} \mathrm{C}$ & $3.53 \pm 0.02^{\mathrm{a}}$ & $6.927 \pm 0.353^{b}$ & $17.60 \pm 1.14^{\mathrm{a}}$ & $82.27 \pm 2.80^{b}$ & $2.81 \pm 0.34^{b}$ & $104.44 \pm 0.09^{d}$ & $315.13 \pm 3.31^{b, c}$ & $7.980 \pm 0.081^{b}$ \\
\hline 24 & $20{ }^{\circ} \mathrm{C}$ & $3.54 \pm 0.01^{\mathrm{a}}$ & $7.375 \pm 0.201^{b}$ & $17.65 \pm 0.21^{\mathrm{a}}$ & $86.40 \pm 1.32^{a}$ & $2.59 \pm 0.14^{b}$ & $96.07 \pm 1.93^{\mathrm{e}}$ & $330.57 \pm 1.54^{\mathrm{b}}$ & $6.876 \pm 0.029^{c}$ \\
\hline
\end{tabular}

* Two means in the same column followed by same letter are not significantly different $(p>0.05)$ by analysis of variance for each temperature. 
The UV-treated juice stored at $4{ }^{\circ} \mathrm{C}$ was also significantly $(p<0.05)$ affected on $\mathrm{pH}$ and Brix degrees parameters. However, the juice stored at $20{ }^{\circ} \mathrm{C}$ remains stable, and $\mathrm{pH}$ and Brix degrees remain without significant $(p>0.05)$ changes up to 24 days.

The effect of storage temperature on the physiochemical parameters is shown in Table 3 . The unique parameter affected by storage temperature was the ascorbic acid content $(p<0.05)$; therefore, the storage temperature does not significantly affect $(p>0.05) \mathrm{pH}$, acidity, Brix degrees, total polyphenol content, antioxidant capacity and color.

Table 3. Temperature effect during storage on quality parameters of UV-treated apple juice.

\begin{tabular}{cc}
\hline Parameter & $p$ \\
\hline pH & 0.928 \\
Malic acid eq. & 0.978 \\
${ }^{\circ}$ Brix & 0.123 \\
Ascorbic acid & $<0.001$ \\
Gallic acid eq. & 0.882 \\
Antioxidant capacity & 0.953 \\
Chroma & 0.714 \\
Hue & 0.362 \\
\hline
\end{tabular}

* Significant $(p<0.05)$ effect of temperature of storage by analysis of variance.

UV-treated juice does not present microbial growth of molds or mesophilic bacteria after treatment and nor during storage time observations.

\section{Discussion}

The total UV dose applied to the apple juice was completely effective to decrease the native microbiota below detection levels. Previously, UV effectiveness was proved for some pathogenic microorganisms. Gabriel et al. [16] determined the UV decimal reduction dose for Salmonella spp, E. coli and Listeria monocytogenes in clear apple juice. They found L. monocytogenes strains where up to three-fold more resistant than other bacteria. In another study, Gachovska et al. [17] achieved a $3.46 \log \mathrm{CFU} / \mathrm{mL}$ of E. coli after UV treatment for $2.3 \mathrm{~s}$. Later, Caminiti et al. [9] treated apple juice with $0.177 \mathrm{~W} / \mathrm{cm}^{2}$, and up to $53.10 \mathrm{~J} / \mathrm{cm}^{2}$. Their minimum treatment of $2.66 \mathrm{~J} / \mathrm{cm}^{2}$ achieved a complete reduction of E. coli and L. inocua from their samples.

In addition, PPO inactivation was completely achieved after UV treatment. Enzymatic activity reduction prevents antioxidant degradation and its inactivation by UV treatment was also previously reported. Falguera et al. [18] obtained a complete inactivation of $A$. bisporus polyphenol oxidase after UV treatment of $35 \mathrm{~min}$ at $0.28 \mathrm{~W} / \mathrm{cm}^{2}$. However, native apple PPO is more resistant, as reported by Falguera et al. [19]. These researchers analyzed the PPO inactivation of four varieties of apples: Golden, Starking, Fuji and David. In all samples of centrifuged juice, PPO was inactive after $100 \mathrm{~min}$ at $0.28 \mathrm{~W} / \mathrm{cm}^{2}$ of UV treatment.

Acidity, $\mathrm{pH}$ and Brix degrees were stable after UV irradiation, as reported previously. Caminiti et al. [9] found UV treatments at any dose did not affect $\mathrm{pH}$, Brix degrees or phenol content, but a decrease in antioxidant capacity was observed after treatment. However, Azhuvalappil et al. [20] and Tandon et al. [21] reported significant changes $(p<0.05)$ in $\mathrm{pH}$, Brix degrees and acidity in apple cider stored at $4{ }^{\circ} \mathrm{C}$ and $7{ }^{\circ} \mathrm{C}$, after UV irradiation with 13 and $14 \mathrm{~mJ} / \mathrm{cm}^{2}$, respectively, but these changes were attributed to microbial spoilage growth and not to UV treatment.

Differences in hue and antioxidant capacity after UV treatment are associated with double bounds disruption and oxidation reactions. These are promoted by UV irradiation and further photon absorption by double bounds or oxygen [22]. Antioxidant capacity of natural apple juice is mainly attributed to phenol antioxidants (87\%) and ascorbic acid (6\%) [23], while Tikekar et al. [24] described a decrease in ascorbic acid content during UV irradiation, up to $0.7-1.0 \mathrm{mg} / \mathrm{min}$ at $0.03 \mathrm{~J} / \mathrm{cm}^{2}$. However, no significant changes $(p>0.05)$ in ascorbic acid content after UV treatment were observed, due to the 
protective effect of phenols [25] and pigments [18,19]. Diminution in TEAC by UV treatment effect was probably due to non-phenol antioxidant oxidation.

During storage, TEAC reduction due to ascorbic acid oxidation was observed, since polyphenol content remained with minimal variations. Ascorbic acid content decreased significantly faster in juice stored at $4{ }^{\circ} \mathrm{C}$ when compared with juice stored at $20^{\circ} \mathrm{C}$, but remained present for all storage time. However, contrary behavior was observed in polyphenol content, which decreases faster in samples stored at $20^{\circ} \mathrm{C}$ than in those stored at $4{ }^{\circ} \mathrm{C}$. This could be attributed to the different antioxidant activity of polyphenols and ascorbic acid at different temperatures. Polyphenols and ascorbic acid present higher antioxidant activity at ambient temperatures than lower temperatures [24,26]. In this sense, ascorbic acid can be the main antioxidant source at $4{ }^{\circ} \mathrm{C}$ and be degraded first and conversely at $20{ }^{\circ} \mathrm{C}$, and polyphenols could be more reactive as an antioxidant source than ascorbic acid. Other authors also reported temperature-dependent degradation rates for ascorbic acid during storage. Marti et al. [27] observed a complete oxidation of ascorbic acid in pomegranate juice after four days of storage at $5{ }^{\circ} \mathrm{C}$ and $25{ }^{\circ} \mathrm{C}$, but nevertheless, at $25{ }^{\circ} \mathrm{C}$, ascorbic acid decreases $25 \%$ faster than that stored at $5{ }^{\circ} \mathrm{C}$. Also, they reported that in a model system, ascorbic acid remained present up to 30 days at $5^{\circ} \mathrm{C}$.

Antioxidants also prevent color changes [28]. Hue variation during UV treatment was referred to oxidation reactions during treatment. On storage, hue does not present significant changes, while chroma decreased significantly, probably due to pigment oxidation or to a partial reactivation (enzyme resistant fraction) of apple PPO as observed by Juarez-Enriquez et al. [11].

\section{Conclusions}

UV treatment of apple juice offers an alternative to achieving a complete reduction of PPO activity and microbiota, becoming an attractive option to pasteurize apple juice in the food industry. After apple juice irradiation with ultraviolet light, polyphenols and ascorbic acid remain in the juice up to 24 days of storage at $20^{\circ} \mathrm{C}$. This implies UV-treated apple juice can be stored at ambient temperatures, ensuring antioxidant consumption.

Acknowledgments: A scholarship grant for the MSc degree of author Juarez-Enriquez (Student registration number: a213548) was provided by the National Council of Science and Technology (CONACYT, Mexico).

Author Contributions: The present study was performed by Edmundo Juarez-Enriquez under direct supervision of Enrique Ortega-Rivas. Ivan Salmerón provided advice on instrumental methods of chemical analyses while Nestor Gutierrez-Mendez was the main consultant on statistical analysis and data interpretation. All authors read and approved the final manuscript.

Conflicts of Interest: The authors declare no conflict of interest.

\section{References}

1. Ravn-Haren, G.; Dragsted, L.; Buch-Andersen, T.; Jensen, E.; Jensen, R.; Németh-Balogh, M.; Paulovicsová, B.; Bergström, A.; Wilcks, A.; Licht, T.; et al. Intake of whole apples or clear apple juice has contrasting effects on plasma lipids in healthy volunteers. Eur. J. Nutr. 2013, 52, 1875-1889. [CrossRef] [PubMed]

2. Barth, S.; Koch, T.L.; Watzl, B.; Dietrich, H.; Will, F.; Bub, A. Moderate effects of apple juice consumption on obesity-related markers in obese men: Impact of diet-gene interaction on body fat content. Eur. J. Nutr. 2012, 51, 841-850. [CrossRef] [PubMed]

3. Gerhauser, C. Cancer chemopreventive potential of apples, apple juice, and apple components. Plant Media 2008, 74, 1608-1624. [CrossRef] [PubMed]

4. Kahle, K.; Huemmer, W.; Kempf, M.; Scheppach, W.; Erk, T.; Richling, E. Polyphenols are intensively metabolized in the human gastrointestinal tract after apple juice consumption. J. Agric. Food Chem. 2007, 55, 10605-10614. [CrossRef] [PubMed]

5. Van der Sluis, A.A.; Dekker, M.; Skrede, G.; Jongen, W.M.F. Activity and concentration of polyphenolic antioxidants in apple juice. 1. Effect of existing production methods. J. Agric. Food Chem. 2002, 50, 7211-7219. [CrossRef] [PubMed] 
6. Noci, F.; Riener, J.; Walkling-Ribeiro, M.; Cronin, D.A.; Morgan, D.J.; Lyng, J.G. Ultraviolet irradiation and pulsed electric fields (PEF) in a hurdle strategy for the preservation of fresh apple juice. J. Food Eng. 2008, 85, 141-146. [CrossRef]

7. Donahue, D.W.; Canitez, N.; Bushway, A.A. UV inactivation of E. Coli o157:H7 in apple cider: Quality, Sensory and Shelf-Life Analysis. J. Food Process. Preserv. 2004, 28, 368-387. [CrossRef]

8. Basaran, N.; Quintero-Ramos, A.; Moake, M.M.; Churey, J.J.; Worobo, R.W. Influence of apple cultivars on inactivation of different strains of Escherichia coli O157:H7 in apple cider by UV irradiation. App. Environ. Microbiol. 2004, 70, 6061-6065. [CrossRef] [PubMed]

9. Caminiti, I.; Palgan, I.; Muñoz, A.; Noci, F.; Whyte, P.; Morgan, D.; Cronin, D.; Lyng, J. The effect of ultraviolet light on microbial inactivation and quality attributes of apple juice. Food Bioprocess Technol. 2012, 5, 680-686. [CrossRef]

10. Juarez-Enriquez, E. Evaluation of Traditional Thermal Method (HTST-UHT) and Alternative Methods (UV and HPP) on Clarified Apple Juice Pasteurization; Autonomous University of Chihuahua: Chihuahua, Mexico, 2013.

11. Juarez-Enriquez, E.; Salmeron-Ochoa, I.; Gutierrez-Mendez, N.; Ramaswamy, H.S.; Ortega-Rivas, E. Shelf life studies on apple juice pasteurised by ultrahigh hydrostatic pressure. LWT-Food Sci. Technol. 2015, 62, 915-919. [CrossRef]

12. Gómez, P.; Salvatori, D.; García-Loredo, A.; Alzamora, S. Pulsed light treatment of cut apple: Dose effect on color, structure, and microbiological stability. Food Bioprocess Technol. 2012, 5, 2311-2322. [CrossRef]

13. Igual, M.; Contreras, C.; Camacho, M.M.; Martínez-Navarrete, N. Effect of thermal treatment and storage conditions on the physical and sensory properties of grapefruit juice. Food Bioprocess Technol. 2014, 7, 191-203. [CrossRef]

14. Fernández-Vázquez, R.; Stinco, C.M.; Hernanz, D.; Heredia, F.J.; Vicario, I.M. Colour training and colour differences thresholds in orange juice. Food Qual. Preference 2013, 30, 320-327. [CrossRef]

15. Cano, M.P.; Hernandez, A.; de Ancos, B. High pressure and temperature effects on enzyme inactivation in strawberry and orange products. J. Food Sci. 1997, 62, 85-88. [CrossRef]

16. Gabriel, A.A.; Nakano, H. Inactivation of salmonella, E. Coli and listeria monocytogenes in phosphate-buffered saline and apple juice by ultraviolet and heat treatments. Food Control 2009, 20, 443-446. [CrossRef]

17. Gachovska, T.K.; Kumar, S.; Thippareddi, H.; Subbiah, J.; Williams, F. Ultraviolet and pulsed electric field treatments have additive effect on inactivation of E. Coli in apple juice. J. Food Sci. 2008, 73, M412-M417. [CrossRef] [PubMed]

18. Falguera, V.; Pagán, J.; Garza, S.; Garvín, A.; Ibarz, A. Inactivation of polyphenol oxidase by ultraviolet irradiation: Protective effect of melanins. J. Food Eng. 2012, 110, 305-309. [CrossRef]

19. Falguera, V.; Pagán, J.; Ibarz, A. Effect of UV irradiation on enzymatic activities and physicochemical properties of apple juices from different varieties. LWT-Food Sci. Technol. 2011, 44, 115-119. [CrossRef]

20. Azhuvalappil, Z.; Fan, X.; Geveke, D.J.; Zhang, H.Q. Thermal and nonthermal processing of apple cider: Storage quality under equivalent process conditions. J. Food Qual. 2010, 33, 612-631. [CrossRef]

21. Tandon, K.; Worobo, R.W.; Churey, J.J.; Padilla-Zakour, O.I. Storage quality of pasteurized and UV treated apple cider. J. Food Process. Preserv. 2003, 27, 21-35. [CrossRef]

22. Guerrero-Beltrán, J.A.; Barbosa-Cánovas, G.V. Inactivation of saccharomyces cerevisiae and polyphenoloxidase in mango nectar treated with UV light. J. Food Prot. 2006, 69, 362-368. [PubMed]

23. Miller, N.J.; Rice-Evans, C.A. The relative contributions of ascorbic acid and phenolic antioxidants to the total antioxidant activity of orange and apple fruit juices and blackcurrant drink. Food Chem. 1997, 60, 331-337. [CrossRef]

24. Tikekar, R.V.; Anantheswaran, R.C.; LaBorde, L.F. Ascorbic acid degradation in a model apple juice system and in apple juice during ultraviolet processing and storage. J. Food Sci. 2011, 76, H62-H71. [CrossRef] [PubMed]

25. Clegg, K.M.; Morton, A.D. The phenolic compounds of blackcurrant juice and their protective effect on ascorbic acid. Int. J. Food Sci. Technol. 1968, 3, 277-284. [CrossRef]

26. Pinelo, M.; Rubilar, M.; Jerez, M.; Sineiro, J.; Núñez, M.J. Effect of solvent, temperature, and solvent-to-solid ratio on the total phenolic content and antiradical activity of extracts from different components of grape pomace. J. Agric. Food Chem. 2005, 53, 2111-2117. [CrossRef] [PubMed]

27. Martí, N.; Pérez-Vicente, A.; García-Viguera, C. Influence of storage temperature and ascorbic acid addition on pomegranate juice. J. Sci. Food Agric. 2002, 82, 217-221. [CrossRef] 
28. Choi, M.H.; Kim, G.H.; Lee, H.S. Effects of ascorbic acid retention on juice color and pigment stability in blood orange (Citrus sinensis) juice during refrigerated storage. Food Res. Int. 2002, 35, 753-759. [CrossRef] article distributed under the terms and conditions of the Creative Commons by Attribution (CC-BY) license (http://creativecommons.org/licenses/by/4.0/). 